\title{
Gauweiler and OMT: Lessons for EU Public Law and the European Economic and Monetary Union
}

\author{
Herwig C.H. Hofmann
}

\section{A Introduction}

Do exceptional situations make exceptional good or exceptionally bad law? This is an old question often asked anew - especially in the context of the post-2008 economic crises travails of the European Economic and Monetary Union (EMU). The legal disputes which resulted from differing opinions about how to solve the crises and also how, incidentally, to improve the EMU's governance have reached the Court of Justice of the European Union (CJEU). The most prominent case to date is the so called Gauweiler case, a preliminary reference procedure initiated by the German Constitutional Court, the Bundesverfassungsgericht (BVerfG). ${ }^{1}$

Gawweiler concerns the legality of the decision of the Governing Board of the European Central Bank (ECB) of September 2012 on so called 'Outright Monetary Transactions' (OMT). This case is significant for legal integration in the EU since, although this case is the first which the German BVerfG has ever referred to the CJEU in a preliminary reference procedure (Article 267 TFEU), the reference by the BVerfG was formulated in very terse words. ${ }^{2}$ Essentially, the reference asks for clarification about the legality of the ECB's OMT decision. But that reference is not formulated in terms of a dialogue between Courts, each respecting the other's distinctive powers. Instead, the BVerfG explains why it considers the ECB's decision to be ultra vires of its mandate and askes the CJEU essentially to confirm this interpretation warning about potential consequences in its assessment about the 'constitutional identity' of the Federal Republic of Germany. Inherent is a thinly veiled threat to not accept the exclusive competence of the CJEU to review the legality of EU law and, instead, to unilaterally hold an act of an EU institution to be invalid within a Member State of the EU. The BVerfG reinforced its sceptical position of the primacy of EU law over the law of Member States by recalling in its decision for preliminary reference its case-law concerning the limits it perceives are set

\footnotetext{
${ }^{1}$ Case C-62/14 Ganweiler and Others v Deutscher Bundestag (OMT) of 16 June 2015, ECLI:EU:C:2015:400.

${ }^{2}$ Request for a preliminary ruling from the Bundesverfassungsgericht (Germany) lodged on 10 February 2014 - Peter Gauweiler and Others, BVerfG, 2 BvR 1390/12 of 17.12.2013, http://www.bverfg.de/entscheidungen/rs20131217 2bvr139012.html.
} 
for the Federal Republic of Germany's integration in the European Union. In its decision, it refers to and further interprets the scope of its own case-law making reference inter alia to its judgments concerning the Treaty of Maastricht, ${ }^{3}$ the Treaty of Lisbon $^{4}$ and in Honeywell, ${ }^{5}$ as precedent for its questions to the CJEU.

This approach to formulating the preliminary ruling, a legal obligation for any court of a Member State of the EU 'against whose decisions there is no judicial remedy under national law' (Article 267 para 3 TFEU) can therefore not be seen as a long overdue normalisation of the relations between the CJEU and the BVerfG. The BVerfG as one of the last remaining constitutional courts of Member States instead of simply complying with its clearly defined obligations under the Treaties to submit in adequate cases questions for preliminary reference. Rather, it is formulated as 'last warning' by the BVerfG after which, if the CJEU does not fall in line with its approach, it would consider to radically challenge the constitutional order of the EU and, in effect, questioning the Union's very existence as a constitutional order.

This is a remarkable effect of what might be, in the cold light of day, regarded as a dispute which in its essence arises from a nearly hypothetical question essentially of administrative-law nature of action of an independent agency - albeit admittedly, an agency created by the constitutional order and action which may have significant financial implications for the budgets of the underwriting Member States. Although the Treaties are being considered as its 'constitutional charter' - the TEU, TFEU and the Charter of Fundamental Rights of the European Union - in parts contain law which in earlier days was referred to as truly a constitutional 'traité cadre' and in parts contains detailed provisions, normally found in legislative acts, sometimes referred to as provisions of 'traité loi'. The question of the development and limits of the ECB's monetary policy are developed in the context of traité loi: The ECB is designed as a highly independent EU agency with a legal basis and detailed Statutes on the level of the Treaties. The provisions not only circumscribe the objectives of monetary policy but also the instruments to great detail. They also confer normative powers as well as powers to enter into contractual relations.

Against the background of this conflict, this paper does not focus predominantly on the, no doubt, eminently important questions of the constitutional relation between EU law and the law of the Member States. Nor does it address primarily the conceptual discussions of the past years, notably how to best frame the pluralism of legal orders in

\footnotetext{
${ }^{3}$ BVerfGE, 89, 155 of 12 October 1993.

${ }^{4}$ BVerfGE, 123, 267 of 30 June 2009.

52 BvR 2661/06 of 6 July 2010.
} 
the EU - or how much hierarchic elements are necessary in this relation between legal orders in order to maintain a Union under the rule of law. Instead, this contribution focusses on the question what general lessons the Gauweiler case will teach for the development of public law in Europe. The reason for this question is that the setting of the case between detailed provisions on a constitutional level and the essentially administrative nature of the activities in combination with nature of the contested decision of the ECB as an emergency measure raises a sufficient amount of questions important enough to be discussed in their own right. It allows disregarding for a moment the BVerfG's judicial threats to breach the primacy of Union law over the essentially hypothetical consequences of a not yet finally developed and not yet implemented future bond purchasing policy of the ECB. This paper therefore essentially looks at what we can learn for EU public law from the OMT dispute leading to Gauweiler. Have the exceptional emergency acts of the ECB - the OMT decision created through the subsequent judicial review anything of value for concepts of European public law, and, if so, which?

\section{B Background - the OMT dispute}

One of the European Union's most ambitious policy projects to date is the "economic and monetary union whose currency is the euro" (EMU, Article 3(4) TEU). The EMU's two polices - the economic union and the monetary union - are an unequal set of twins. On one hand, the monetary union's central elements are developed to great detail in the Treaties. They provide not only for provisions containing the introduction of the Euro as a single currency; but also institutionally, for the creation of the European System of Central Banks (ESCB) with the European Central Bank (ECB) on the EU level as a highly independent body equipped with the power to adopt specific forms of act. Additionally, the Treaty is specific about policy goals and principles of monetary policy.

The economic union, on the other hand, is much less developed on the Union level. The original approach in the Treaty of Maastricht of 1992 was to leave economic - and fiscal - policies largely within the competence of the Member States with the establishment of only loose mechanisms of intergovernmental cooperation. Market pressures, so the original thinking behind the loose structure, would in the long run ensure that national policy choices by the elected parliaments and governments on the Member State levels and align them with each other to form a coherent whole. ${ }^{6}$

\footnotetext{
${ }^{6}$ One possible explanation for the distinction between the monetary and the economic policy in the Treaties is that it had originally been based on the assumption that the key to stable growth in the economy was 'sound' monetary policy conducted by technical experts in independent central banks (see e.g. Peter A. Hall, The Mythology of European Monetary Union, 18 Swiss Political Science Review (2012), 508513 at 508). Active fiscal policy, was deemed counterproductive and it would have appeared inopportune to give the monetary union capacities for coordinating its member states' fiscal policies (see e.g. Tal Sadeh, Amy Verdun, Explaining Europe’s Monetary Union: A
} 
In view of this situation, a key challenge for a unified monetary policy in the EU has been the resulting potential mismatches of policy approaches in these two highly interrelated policy fields. ${ }^{7}$ Irrespective of the very different treatment of the monetary and economic policies in the EMU, the two are highly inter-related. Monetary policy, largely set by the ECB and implemented by the ESCB, takes place alongside of and in coordination with fiscal policy measures, which typically include taxation or debtfinancing of public budgets and the allocation of available funds in national budgets and social security systems. The broader economic policy orientation of Member States also includes issues of regulation, for example, through labour law, competition law or energy law. Monetary policy is created by reacting to and commenting on economic policy decisions of Member States. Therefore, the ECB, as a highly specialised European body, may risk overstepping into matters of economic policy. Drawing the boundaries is not easy. In exercising its task of designing the correct monetary policy for the Eurozone, the ECB cannot ignore the structure and the state of the economy. In fact, it might have more information about the reality of the economic situation than many Member State governments.

The contested OMT decision of the ECB was taken in a time of particular market unrest. Doubts about the future of the EMU were rampant. The cost of borrowing money on the markets rose sharply for some Member States of the EU, in some instances, arguably, rather independently of the underlying creditworthiness of the public treasuries trying to sell its government bonds. At that time, the president of the ECB, Mario Draghi, made a widely cited speech stating that within its mandate, "the ECB is ready to do whatever it takes to preserve the euro." To this he added: "And believe me, it will be enough.",

One month later, at a press conference after a meeting of the ECB's Governing Council of 6 September 2012, the president of the ECB announced to the public the decision to conduct the OMT-programme and gave some details. Essentially the ECB announced that it would develop a programme the legal details were yet to be decided by legal instruments. In its statement, the ECB declared that it was ready to purchase on secondary markets government bonds issued by States of the euro area, subject to

Survey of the Literature, 11 International Studies Review (2009), 277-301 at 285 with further references). The fact that this distinction allowed for the creation of a monetary union without the necessity of the transfer of a wide range of fiscal and general economic policy powers to the EU might help explain the striking differences in structure between the monetary and the economic union within the EMU.

${ }^{7}$ The objectives and administrative tasks of the economic and monetary union (Article 3(4) TEU) are outlined in Article 119 TFEU according to which the activities of the Member States and the Union under monetary policy include "the adoption of an economic policy which is based on the close coordination of Member States' economic policies, on the internal market and on the definition of common objectives, and conducted in accordance with the principle of an open market economy with free competition" and creating and administering "a single currency, the euro, and the definition and conduct of a single monetary policy and exchange-rate policy (...)." ${ }^{8}$ Speech by Mario Draghi, President of the ECB at the Global Investment Conference in London, 26 July 2012, http://www.ecb.europa.eu/press/key/date/2012/html/sp120726.en.html. 
certain conditions which included that, first, states concerned had to be subject to financial assistance by either the European Financial Stability Facility ("EFSF") 9 or the European Stability Mechanism ("ESM"), ${ }^{10}$ two structures put into place by Member States in the context of the European economic policy to stabilise States in financial difficulties. Second, no quantitative limits for the amount of purchases of these government bonds were announced. Third, the ECB would act in the same way as any private creditors and therefore not benefit from a special status as public actor. Finally, the ECB announced that any liquidity so created would be fully 'sterilised', indicating that the ECB wished to avoid the creation of additional money in circulation.

This announcement sufficed to reduce the in view of the ECB extreme spreads and the high volatility of the interest rates charged for government bonds of various States using the Euro which had not been based on macroeconomic differences between the States but were based on speculation as to the breaking up of the Eurozone. The announcement was never followed up by any binding ECB legal instruments or decisions to put the OMT programme in place and was consequently never implemented. The ECB did however, formally unrelated to the actual OMT programme, begin in March 2015 a landmark $€ 60$ billion per month so called 'quantitative easing' programme in which it buys government bonds on the secondary markets. The mere announcement had however the power to calm the markets. Since 2012 there have been no more extreme spreads of the kind which led the ECB to make its announcement.

Against this background, the dispute in Gawweiler arose. The BVerfG essentially asked the CJEU whether the ECB overstepped its powers which have been conferred on it in the Treaties relating primarily to monetary policy. Did the ECB act ultra vires in venturing into economic policy - a matter reserved in the EU's federal structure to the Member States? ${ }^{11}$ The BVerfG's reference to the CJEU for a preliminary ruling raises the question, first, whether the OMT programme, rather than being a monetary policy measure under Article 18 ESCB Statute and Article 119 TFEU, is in fact an economic policy measure, which would fall outside the scope of the ECB's mandate. Secondly, the German court is doubtful whether the measure complies with the prohibition of monetary financing of the Member States laid down in the provisions of the EU economic union in Article 123 TFEU. It is a familiar pattern to public law: Interesting constitutional questions arise from matters with an administrative background.

\footnotetext{
${ }^{9}$ The European Financial Stability Facility, is a special purpose vehicle, outside the EU Law framework, established as a private company under Luxembourg law with the EU member states as shareholders.

10 The European Stability Mechanism (ESM) is the permanent crisis resolution mechanism for the countries of the euro area. The intergovernmental treaty under public international law establishing the ESM was adopted on 2 February 2012.

${ }^{11}$ Additionally, the BVerfG asks the question, whether the OMT decision, by allowing for the purchase of particular Euro member government bonds on the so called secondary market violates the prohibition of monetary financing of state debt laid down in Article 123(1) TFEU.
} 
questions. However, the underlying concern in the German debate voiced also by some of the plaintiffs in the original dispute before the BVerfG was that if the ECB were to move ahead with its bond-buying programme, this might risk exposing the ECB to such degree of obligations that ECB risked itself to go bankrupt. In this case, the Member States, being the ultimate shareholders of the ECB, would be held liable for the losses which in turn would affect the budgetary powers of the national parliaments.

\section{$C$ Reviewing an announcement of a possible future policy programme}

Essentially, the ECB had announced a detailed plan to undertake future market interventions by means of entering into purchase agreements on the open markets of government bonds. This announcement is made in a dramatic moment with great market unrest. The ECB uses its status and credibility to declare an emergency measure to be imminent. But legally speaking, an obvious question normally consists of the fact whether such announcement, or the underlying decision to make such de facto announcement, can or should be subject to any judicial review. Does the fact that a measure is an emergency measure change anything in this respect?

\section{a) Review of Regulation by Information}

Generally, administrative action that is explicitly or implicitly designed to have factual, as opposed to legal, consequences or effects can be referred to as 'factual conduct' or 'factual act' in order to distinguish them from formal, legally effective measures. ${ }^{12}$ Neither in the EU context nor in the context of national legal systems does factual conduct occur in a legal vacuum. Rules and principles of EU administrative law frame establishing both criteria for the legality cases of factual conduct and the consequences of the illegality. Normally the legality of any factual act undertaken by an EU institution would be open to review within the procedure for a preliminary ruling by the ECJ under Article 267 TFEU. ${ }^{13}$ That is the case in the BVerfG reference to the CJEU in Gauweiler. Unusual, but inherent in the system of legal review of the Court system in Europe which is separated by national and European levels, is that a national Court such as the German Constitutional Court, can by broadly interpreting its admissibility criteria achieve broad review by the CJEU of diverse categories of action of EU institutions and

\footnotetext{
12 Expressions found in the language of some of the legal systems of the Member State include acte juridique and fait materiel (French) and Realakt and schlichtes/informales Verwaltungshandeln (German).

13 The latter, unlike Art. 230 EC (Art. 263 TFEU), allows for the review of any forms of acts by the institutions. Unlike Art. 230 EC (Art. 263 TFEU), does not require that acts intended to produce legal effects vis-à-vis third parties.
} 
bodies. The CJEU principles has the obligation of answering questions submitted to it by a national court. It is recognised in EU law that a purely factual measure or other factual conduct, lacking in itself formal legal status or character, may amount to the implementation, at least implicitly or tacitly, of a decision.

In Gauweiler, however, it is necessary to try to assess the nature of the act. The ECB held a press conference announcing a decision by its Governing Board. That decision was to be aimed at taking future binding legal acts which were to determine to greater detail the specific circumstances of action. However, it is undisputed that after this announcement, few would have doubted that the ECB would consider doing so at short notice. Also, it is undisputed that the announcement was already fairly detailed as to the conditions the Governing Board of the ECB had set as criteria for future action. Yet, legally speaking, the only 'act' subject to review was the announcement itself. It would appear that the factual act arises here from the ECB issuing a public statement.

Information policy being reviewed under conditions of factual conduct is not limited to monetary policy. Monetary policy is merely one example of public communication having become a key tool of regulation. 'Regulation by information' as it is generally known is a central element of public activities used in many policy areas. Within the EU, the European Commission applies this approach to further the goals of the Treaties. Publication within fields of Union competences can be either in the form of information of interested parties about decision-making criteria and practices or in the form of establishing performance benchmarks and reporting about Member States' or other actors' performance. In the context of monetary policy, the ECB, as European agency, has the explicit legal obligation to communicate widely and transparently. Communication is one of the respected tools of this field by which the ECB can influence markets in order to conduct its policies.

All of this cannot, however, deter from the fact that the ECB announcement was a situation of mere factual conduct. In reviewing this, the CJEU confirms the criteria of legality for such acts. First, the criteria of legality must be the same as for other implementing actions of EU authorities. Thus, the institution or authority will need to be competent to act within the policy area and be authorised to using the form of measure concerned. In other words, the competence must extend not only to the question of how to act (that is, the means) but also to the question of whether to act (that is, the subject matter and purpose). A further significant test of legality relates to the limits upon the action to be taken. Specifically, the institution or body undertaking the factual measure, that is, engaging in the factual conduct, must respect and meet the standards of the general principles of law which generally govern the legality of Union 
acts, such as the principles of proportionality and the protection of fundamental rights and others. ${ }^{14}$ In other words, the test of legality of factual conduct should not differ from that applicable to formal measures taken by the administration. In Ganweiler the CJEU explicitly confirms this approach as set of criteria for review of the announcement of the OMT programme by the ECB. It first reviews its legal basis and whether the ECB had acted ultra vires the powers conferred on it in its enabling law - the Treaties and the Statutes of the ESCB - before reviewing compliance with general principles of EU law such as, most importantly, the principle of proportionality.

The CJEU's confirmation in Gauweiler of the importance of regulating information and the confirmation of the criteria for review are an important clarification. Only due to the questions raised in the context of the preliminary reference from the BVerfG, does the CJEU acknowledge this approach. No direct actions for annulment under Article 263 TFEU would have been admissible so that the Court might not have had opportunity to so clearly express its views on the criteria for legality and review. ${ }^{15}$

b) Review of a general programme

The CJEU's Advocate General in the case, Cruz Villalón, had pointed out another specificity of the review question addressed to the CJEU: The question for him is how to conduct judicial review 'where the impugned act is a measure outlining a general programme of action, intended to bind the actual authority which is the author of the decision.' The question is, therefore, should there be any difference between review of such general but internal programme as opposed to review of 'an act that contains a measure which creates rights and obligations with regard to third parties.' Review of a programme should take place, according to the $A G,{ }^{16}$ since general action programmes of public authorities may be capable of having a very direct impact on the future legal situation of individuals. This, so the AG 'justifies taking a non-formalistic approach" when considering whether it should reviewed.' 'Otherwise, there would be a risk that an institution could undermine the system of acts and the corresponding judicial safeguards by disguising acts that are intended to produce external effects as general programmes. ${ }^{17}$ The CJEU implicitly follows implicitly this line. It submits the announcement of the OMT programme to the same criteria for judicial review as any other factual act it comes

\footnotetext{
14

${ }^{15}$ Case C-62/14 Gauweiler and Others v Deutscher Bundestag (OMT) of 16 June 2015, ECLI:EU:C:2015:400, paras 32-126.

${ }^{16}$ Opinion of AG Cruz Villalón of 14 January 2015 in Case C-62/14 Gauweiler and Others v Deutscher Bundestag (OMT), ECLI:EU:C:2015:400, paras 75. 76

17 Opinion of AG Cruz Villalón of 14 January 2015 in Case C-62/14 Gauweiler and Others v Deutscher Bundestag (OMT), ECLI:EU:C:2015:400, paras 75. 76
} 
to review. In fact, it can rely on a long tradition of case law doing so reaching back over forty years. In ERTA the CJEU reviewed a Council position paper coordinating Member States in the negotiations for the conclusion of an international agreement which was subject to judicial review, because it was capable of 'derogating ... from the procedure laid down by the Treaty'. ${ }^{18}$

The CJEU does not enter into this debate simply approaching the question of review of the programme as it would do with any other factual act, the legal nature is not entirely clear. It can leave this question open in this specific situation of litigation, because the question presented to it comes from a national Court which does not appear to have any difficulties working with the nature of the plan. The BVerfG, as the CJEU points out, appears to regard the ECB announcement, because of the details given in the press declaration about the future programme, to be sufficiently precise in order to be able to review its legality. This approach is, it should be mentioned, entirely consistent with the CJEU's approach in its review under Article 318(11) TFEU of future international agreements. That article specifically speaks of "agreements envisaged", a term interpreted by the CJEU interprets broadly requesting only the subject matter of the agreement to be known. ${ }^{19}$ Even before negotiations have started and a specific text being presented, the specific procedure is admissible, according to the Court as long as it has sufficient information about the content and the basic structural elements of the plan for the envisaged agreement. ${ }^{20}$

\section{Full review of compliance with the legal basis and its limitations}

According to the above, the judicial review of the announcement of the OMT programme by the ECB then follows the two-tier approach of looking at first, whether the programme has a legal basis and whether it violates any legal norms its powers are subject to. Second, the Court reviews whether the measure complies with general principles of EU law, notably the principle of proportionality to which any act of an EU body is subject to. The review of proportionality is the moment where the real question of the degree of review of the discretionary powers of a highly independent agency will be asked.

a) Does the ECB have a legal basis?

\footnotetext{
${ }^{18}$ Case 22/70 ERTA, EU:C:1971:32, para 54.

${ }^{19}$ See e.g. Opinion 1/78 international agreement on natural rubber [1979] ECR 2871, paras 32-34.

${ }^{20}$ See e.g. Opinion 1/94 Accession by the Communities to the Convention for the Protection of Human Rights and Fundamental Freedoms [1996] ECR I1759, paras 11-12.
} 
Review of any act of an EU body, be it legislative or administrative in nature is subject to full review as to compliance with the legal basis. This is a question of what the Court calls 'objective criteria'. The degree to which the legal system has regulated a matter by higher ranking law may vary. In case of the ECB, an EU agency which has been created by Treaty provisions and which is regulated to a high degree by what can be referred to as 'traité-loi'. Therefore, in tune with the degree of detail of the legal framework of the matter, judicial review of such activity can be equally detailed. In interpreting legal basis, a method of interpretation of borrowed from public international law which looks for the teleological intention to ensure the effet utile (effectiveness) of the measure.

In that sense, the CJEU starts with an analysis of the legal framework and the objectives of monetary policy. It focusses specifically on the fact that monetary policy of the Union under Article 119(2) TFEU must ensure a 'single currency, the euro, and the definition and conduct of a single monetary policy and exchange-rate policy' ${ }^{21}$ Therefore any monetary policy must be oriented towards a 'single policy' for the Union.

The legal framework for action of the ECB to work towards this task is regulated in the chapter on monetary policy of the TFEU as well as in the Statutes of the ESCB, annexed to the Treaties as protocol No 4, which grants the Statutes the same legal value as the Treaties themselves. The ECB's mandate is quite precisely defined in the TFEU, which in its Article 127 states that its "the primary objective" "is to maintain price stability" (emphasis added). However, Article 127 TFEU also explicitly states that without prejudice to this objective, monetary policy shall support the 'general economic policies in the Union... .' With this mandate, a fundamentally political powers has been conferred on a very independent administrative body, the ECB. The ECB is designed to concentrate a maximum amount of expertise. Article 282(4) TFEU establishing that the ECB 'shall adopt such measures as are necessary to carry out its tasks.' Its 'monetary functions' are specified in Articles 18-20 of the ESCB Statutes.

Technically, the OMT programme therefore fell under the powers granted to the ECB under Article 18 of the ESCB Statutes under which the ECB may conduct so called 'open market and credit operations'. 'Open market' activities are contractual activities which include buying and selling as well as lending or borrowing 'claims and marketable instruments' as well as conducting 'credit operations with credit institutions and other market participants, with lending being based on adequate collateral." Importantly, under Article 18 of the ESCB Statutes, the ECB is obliged to conduct an information

\footnotetext{
${ }^{21}$ Both of which is to be undertaken with the primary objective 'to maintain price stability and, without prejudice to this objective, to support the general economic policies in the Union, in accordance with the principle of an open market economy with free competition'. Article 119(2) TFEU.
} 
policy by establishing also a policy "for the announcement of conditions under which they stand ready to enter into such transactions."

In this context, European monetary law contains many familiar features but is also characterized by certain specificities when compared with other areas of European administrative law. Monetary policy for the EU is conducted by the European Central Bank (ECB) in conjunction with the NCBs of the EU Member States which have joined the Eurozone. ${ }^{22}$ The ECB is in some ways structured similarly to an EU agency with a legal basis in the Treaties. ${ }^{23}$ Similar to many agencies, the ECB is a centre of Union expertise. Monetary policy is an area that requires great technical expertise to manage and entails large and substantive risks for the economic wellbeing of all citizens and for the financial positions of the Member States. For that reason, it is an eminently political area of law. ${ }^{24}$ The ECB's organs are the Governing Council and an Executive Board. ${ }^{25}$

Within the ECB, the ECB's Governing Council has the central tasks of formulating the monetary policy of the Union by adopting the guidelines and takes the decisions 'necessary to ensure the performance of the tasks entrusted to the ESCB under these Treaties and this Statute'. This includes, under Article 12(1) Statutes ESCB, decisions relating to 'intermediate monetary objectives, key interest rates and the supply of reserves in the ESCB'.

By contrast, very few legal provisions had been put in place to implement the economic policy within the European 'economic and monetary union' prior to the onset of the economic crises in 2008. The Treaty of Maastricht had left incomplete a possible economic policy union despite the "the monetary and economic union" (Article 3 TEU) containing "two integral parts of a single whole" which would have to be implemented in parallel. ${ }^{26}$ Much of the field of economic policy cooperation was developed ad hoc in response to the economic crises since 2008. The central legal norm has been Article 126

\footnotetext{
22 As of 2015 the following 18 Member States who had adopted the Euro as their currency: Austria, Belgium, Cyprus, Estonia, Finland, France, Germany, Greece, Luxembourg, Ireland, Italy, Latvia, Lithuania, Netherlands, Portugal, Slovenia, Spain.

23 The ECB evolved out of the European Monetary Cooperation Fund (EMCF) which had been set up by Council Regulation (EEC) No 907/73 of 3 April 1973 (OJ 1973 L 89/2). The EMCF was superseded and its functions assumed by the European Monetary Institute (EMI). This was a temporary body created at the beginning of stage two of the EMU (Article 109f TEC and the EMI statutes attached as a protocol to the TEC).

${ }^{24}$ However there are some important differences between the ECB and the organization of other Union agencies. The relevant Treaty provisions regulate to great detail the internal structure and the independence of the ECB. The ESCB under Article 130 TFEU and the ECB according to its statutes a strictly independent. Under Article 130 TFEU "neither the ECB, nor a national central bank, nor any member of their decision making bodies shall seek or take instructions from Union institutions, bodies, offices or agencies, from any government of a Member State."

${ }^{25}$ Under Article 283 TFEU the ECB's Governing Council comprises the members of the executive board of the ECB and the Governors of the NCBs of the Eurozone states. The NCBs are thereby not represented as institutions but by individuals acting in their capacity as members of an ECB organ. Each member of the Governing Council has one vote exercised in confidential proceedings. But voting rights are not allocated on a one-Member-State-one-vote basis. The number of governors with voting rights is limited to 15 .

${ }^{26}$ Committee for the Study of Economic and Monetary Union, Report on economic and monetary union in the European Community, (Brussels 1989).
} 
TFEU on the prohibition of excessive government deficits. However, these basic provisions have been expanded with structures, some of which seemed to be testing notions of constitutionality via the creative use of existing forms of act. Great creativity was employed to set up structures capable of achieving the objectives amid a divided Union with countries having adopted the Euro and countries not having done so. In essence, with regard to the ECB, the key norm to the dispute is the essential limitation of ECB monetary policies regarding the economic policy decisions. In it, the competences of the ECB are strictly circumscribed by the prohibition of monetary financing of Member State debt by means of direct purchases as opposed to open market operations of the ECB involving Member State bonds (Article 123(1) TFEU).

In Gamweiler the Court finds that in that context, the ECB had the right to design a programme safeguarding its possibilities to ensure that its monetary policy would be capable of contributing to price stability in a single currency area. It accepts the technical evaluations of the ECB that at the moment of the publication of its announcement, interest rates charged for government bonds by different member states had been distorted by speculation about their exit from the Eurozone, and therefore threatening the policy objective of a 'single' currency. 'Since disruption of the transmission mechanism undermines the effectiveness of the measures adopted by the ESCB, that necessarily affects the ESCB's ability to guarantee price stability. Accordingly, measures that are intended to preserve that transmission mechanism may be regarded as pertaining the primary objective laid down in Article 127(1) TFEU. ${ }^{27}$ The CJEU, in its objective review of whether a measure is within the legal basis, nonetheless, has to accept that the expertise of the institution developing a measure must be recognised and that its scientific evaluation of a situation should be respected. Interestingly, the claim made by the ECB that that was so is regarded to be sufficient by the CJEU. The Advocate General spells out quite clearly that the fact, ex post facto, that the Eurozone did not break apart and that the conditions for conducting a single monetary policy was restored is sufficient in the context of this review. ${ }^{28}$ It would appear, however, in principle that a much clearer relation between criteria of full review, scientific expertise and discretion in its evaluation would need to be established in order to ensure a more convincing level or review.

The delimitation of monetary policy - conferred on the ESCB - and economic policy which remains largely with the Member States and the Union legislator - is viewed by he CJEU in Gauweiler as a question of primary versus secondary effects of a measure. In

\footnotetext{
${ }^{27}$ Case C-62/14 Gauneiler and Others v Deutscher Bundestag (OMT) of 16 June 2015, ECLI:EU:C:2015:400, paras 46-49.

${ }^{28}$ Opinion of AG Cruz Villalón of 14 January 2015 in Case C-62/14 Gawweiler and Others v Deutscher Bundestag (OMT), ECLI:EU:C:2015:400, para 84.
} 
reality, the distinction mirrors older case law of the CJEU on the so called 'centre of gravity' rule which was applied in situations where a measure could have several competing legal basis each proposing a different decision making procedure. The Court informs that the fact that a measure in the field of the Union's monetary policy might incidentally also have secondary effects 'on the stability of the euro area', which is a matter of economic policy, does not call that assessment into question. ${ }^{29}$

This is, according to the Court not challenged by the conditionality of the announced bond buying activities of the ECB on compliance of a target country's compliance with the conditions of EFSM and ESM macroeconomic adjustment programmes. The background to this is the following: In reaction to the realities of the lack of common economic policy and in the wake of the economic crises since 2008, the EU had to find ways to deal with various emergency situations. Thus between late 2010 and 2012, a comprehensive reinforcement of economic governance in the EU and the euro area was set in place establishing institutional structures such as the European Stability Mechanism (ESM) ${ }^{30}$ the European Financial Stabilisation Mechanism (EFSM) ${ }^{31}$ and the European Financial Stability Facility (EFSF) ${ }^{32}$ as agreements under public international law outside the Treaty framework. Using public international law was not uncontested but had become necessary by the lack of unanimity in Council. In Pringle the CJEU declared this approach legal, 33 but the negative consequence is that the intergovernmental approach excludes making use of democratic accountability existing within the Union. ${ }^{34}$ The CJEU finds that the discretionary decision by the ECB to request this conditionality is in itself proof of its independence. It is in compliance with the obligations of Article 127(1) TFEU to do nothing that would be able to disencourage Member States to maintain sound finances. ${ }^{35}$ One might argue otherwise.

\footnotetext{
${ }^{29}$ Case C-62/14 Gamweiler and Others v Deutscher Bundestag (OMT) of 16 June 2015, ECLI:EU:C:2015:400, para 51, with reference to C370/12 Pringle EU:C:2012:756, para 56.

30 The European Stability Mechanism (ESM) is the permanent crisis resolution mechanism for the countries of the euro area. The intergovernmental treaty establishing the ESM was adopted on 2 February 2012.

31 The European Financial Stabilisation Mechanism, legally based in Art. 122 (2) TFEU, is a programme whose purpose is to provide loans to EU Member States in financial difficulty.

32 The European Financial Stability Facility, is a special purpose vehicle, outside the EU Law framework, established as a private company under Luxembourg law with the Member States as shareholders.

${ }^{33}$ Case C-370/12 Pringle EU:C:2012:756; with much literature having discussed the legality of the structure. See e.g. See for instance, Mathias Ruffert, 'The European Debt Crisis and European Union Law' (2011) 48 C.M.L. Rev. 1777,1785; Richard Palmstorfer, 'To bail out or not to bail out? The current framework of financial assistance for euro area Member States measured against the requirements of EU primary law' (2012) 37 E.L. Rev., 771-784; Jean-Victor Louis, 'The no-bailout clause and rescue packages' (2010) 47 C.M.L.Rev. 971, 977; Jörn Pipkorn, 'Legal arrangements in the Treaty of Maastricht for the effectiveness of the economic and monetary union' (1994) 31 C.M.L.Rev. 275; Harald Hofmeister 'To Bail Out Or Not to Bail Out?_Legal Aspects of the Greek Crisis', (2010-2011) 13 Cambridge Yearbook of European Legal Studies, 113 - 134.

${ }^{34}$ The chosen approach thus considerably strengthened the executive branch of powers of the Member States. One example is the creation and empowerment in matters of fiscal and economic policies of the 'Eurogroup', a gathering of national ministers of finance. Another effect of this approach is that the ECB was involved, due to its unmatched expertise in monetary policy matters, in the drafting of the conditions of the assistance granted to Member States by the EFSM and the ESM.

${ }^{35}$ Case C-62/14 Gauweiler and Others v Deutscher Bundestag (OMT) of 16 June 2015, ECLI:EU:C:2015:400, paras 58-60.
} 
As the AG has pointed out, the ECB is therefore not neutral in the formulation of the criteria of economic policy of the Member States which are in assistance programmes of the EFSM and the ESM. The ECB would thus, when creating the condition for government bond purchase programmes, in effect, reinforce the incentives to comply with these conditions. ${ }^{36}$ In that sense, the Court is in a catch 22 situation. Should it find that the OMT programme is not actually a combined monetary and economic policy measure? The Court takes this combination as a sign that the ECB complies with the economic policy prerogatives of the Member States but the close knit interaction of the various players is exactly the problem which arises from expert agencies being called upon to advise on specific policies and then to implement them including to designing general implementing schemes. Independent agencies become truly powerful through their exclusive mastery of complex factual situations.

b) Does the ECB comply with the limitations of its mandate?

As indicated, the scope of the ECB's powers in monetary policy matters is particularly narrowly defined in EU constitutional provisions of the Treaties. The competences of the ECB are for example circumscribed by the prohibition of monetary financing of Member State debt by means of direct purchases (as opposed to open market operations of the ECB involving Member State bonds - Article 123(1) TFEU). This prohibition relates to the original concept of creating the European economic and monetary union by means of a centralised monetary policy in combination with a loose cooperation of economic policies. The original pre-crises construct was hoping for the disciplining effect of the financial markets to incite Member States to take sound financial decisions This was supposed to imply a 'competitive' and 'decentralized' model of the macroeconomic European Constitution. ${ }^{37}$ Such a 'market-based system' is premised on the fact that states' in principle should have direct access to financial markets in order to finance their debts. Fiscal indiscipline and unsound public finances would be punished, the market-based model argues, directly through the markets which would stop the lending to the non-compliant state. In this vein, 125 'TFEU ${ }^{38}$ establishes a 'no bail-out clause' in

\footnotetext{
36 Opinion of AG Cruz Villalón of 14 January 2015 in Case C-62/14 Gauweiler and Others v Deutscher Bundestag (OMT), ECLI:EU:C:2015:400, para 156.

37 Miguel Poiares Maduro, We the Court, (Hart Publishing 1998), p. 103 et seq.

38 Article 125 (1) TFEU reads as: "The Union shall not be liable for or assume the commitments of central governments, regional, local or other public authorities, other bodies governed by public law, or public undertakings of any Member State, without prejudice to mutual financial guarantees for the joint execution of a specific project. A Member State shall not be liable for or assume the commitments of central governments, regional, local or other public authorities, other bodies governed by public law, or public undertakings of another Member State, without prejudice to mutual financial guarantees for the joint execution of a specific project".
} 
combination with a strict prohibition on 'monetising' debt through the ECB in Article 123 TFEU. ${ }^{39}$

Again, the review of compliance with the limitations of the independence of the ECB and compatibility of its actions with Article 123 TFEU is subject to full review of the CJEU. Therefore, the CJEU interprets Article 123 TFEU in combination with Article 18.1. of the ESCB Statutes and finds that the ECB may on the financial markets buy and sell outright marketable instruments which include government bonds. This established, the question remains about compliance with these terms, and their possible circumvention.

Although part of the ESCB mandate is transparent communication, the irony of this is that, although the ECB is required to inform transparently about its activities and the announcement of the OMT programme falls within this point, the CJEU has to accept that the ECB can only fulfil the requirements it establishes, if it leaves market participants uncertain about when and how much debt it would buy on the secondary market and how long it would hold the government bonds once purchased, i.e. whether it would resell these bonds or whether it would hold them to maturity.

\section{E Review of the discretionary powers of the ECB}

It would appear that the matters of full review discussed above leave some room for assessment to an EU agency as the ECB. Even in full review, the CJEU has deferred to assessments of factual situations such as the risk for breaking apart of the Eurozone. However, apart from the assessment of the facts leading to the decisions taken by the ECB, the decisions as such are discretionary. It is a situation of deference to the assessment of the input into a decision by an agency and granting of discretion regarding the outcome.

The CJEU accepts that large quantities of statistical information and economic expertise are needed for monetary policy making. The broad legal definition of the ECB's tasks, combined with a constitutionally guaranteed independence of the ECB, this results in very broad discretion of the ECB to decide upon the use of such datea for monetary policy decisions. To exercise this task it has, as AG Cruz Villanón observes in Gauweiler, at its disposal technical expertise and access to crucial information which allows it to

\footnotetext{
${ }^{39}$ Article 125 (1) TFEU reads as: "The Union shall not be liable for or assume the commitments of central governments, regional, local or other public authorities, other bodies governed by public law, or public undertakings of any Member State, without prejudice to mutual financial guarantees for the joint execution of a specific project. A Member State shall not be liable for or assume the commitments of central governments, regional, local or other public authorities, other bodies governed by public law, or public undertakings of another Member State, without prejudice to mutual financial guarantees for the joint execution of a specific project".
} 
devise monetary policies actually influence economic realities. ${ }^{40}$ This type of highly technical, very complex and information intensive activity is, consequently, very difficult to monitor through 'traditional' legal means of a framework of powers and judicial review.

Criteria of accountability are ones are generally applicable in cases of broad discretion. The fewer the possibilities of judicial review as to the substance of the decision of the administration, the more important are procedural considerations as to, for example, compliance with the duty of care (full and independent assessment of all relevant facts prior to decision-making), compliance with the requirement of reasoning of a measure. This in the case law of the CJEU is generally wrapped up in an in-depth review of proportionality.

Gawweiler is a case confirming and reinforcing an existing trend in the EU. Broad discretion conferred on an institution or body will not deter from detailed review under proportionality criteria. The key to this development is, like in many systems, a proceduralisation of review criteria. Compliance with procedural obligations under the principle of proportionality imposes an obligation on Union bodies 'at least to satisfy themselves that the proposed measures are prima facie adequate to attain the legitimate aims pursued. ${ }^{41}$ These questions are linked to the control over the exercise of discretion in judicial review. So far, the review of single case decisions has taken place in the context of the control of the duty of diligent and impartial examination of all aspects of the case. This is closely linked to the obligation to give reasons. Only a sufficiently reasoned decision will indicate compliance with the duty of care and the standards of investigation. Especially in highly fact-based and context determined competition law cases, the GC has limited the obligation of providing reasons for the final decision from the perspective of the satisfaction of the duty of care or diligence. In stating the reasons for decisions, the Commission is not obliged to adopt a position on all the arguments put forward by the parties, but may concentrate its presentation of facts and legal considerations to those having decisive importance for the decision. In a range of situations it will not be sufficient for administrative decision-makers to rely on preexisting knowledge within the authority or on information provided by the parties. Instead, they must have recourse to scientific expertise. The necessity of gathering the latter can be the reason for creating an expert agency and equipping it with specific powers such as the ECB.

\footnotetext{
40 See: Opinion of AG Cruz Villalón in C-62/14 Peter Gauweiler and Others v Deutscher Bundestag of 14 January 2015.

${ }^{41}$ Opinion of Sharpston AG in Case C-310/04 Spain v Council [2006] ECR I-7285 at para 80. The violation of the duty to care by the institutions was so severe that they were criticized as appearing arbitrary: "In the absence of any impact study, certain choices made by the Commission and the Council appear arbitrary" (para 94).
} 
On the basis to deference to the factual assessment of the ECB and its explanations given in and around the press conference leading to the announcement of the OMT programme, the CJEU there finds that under the first leg of the proportionality test, the ECB could reasonably have taken the view that the OMT programme was appropriate to achieve the objectives outlined in the Treaty of conducting a single currency, maintaining price stability in the entire Eurozone and without prejudice to the former also supporting the general economic policies of the Union. ${ }^{42}$ However, this was undertaken in the context of an emergency measure which presumably would reduce the requirements of documentation and increase the margin of appreciation of facts granted to the institution.

The acceptance of the technical expertise and forecasts based on complex assessments by the court in that context must be generally supported by an 'adequate statement of the reasons for its decision'. In this context, of course, the fact that the OMT programme is merely announced at a press conference but still non-existent from a legal point of view, does not allow it to have a statement of reasons.

The Court plays over this problem by stating that ' the press release, together with draft legal acts considered during the meeting of the Governing Council [of the ECB] at which the press release was approved, make known the essential elements of a programme such as that announced in the press release and are as such as to enable the Court to exercise its judicial review.' ${ }^{43}$ Any future plaintiff being rejected because of the inadmissibility of the case because of the preparatory nature of a measure does not qualify as an act in the sense of an act for annulment in the sense of Article 263 TFEU should take note: Where the CJEU for political reasons wants to decide a case, it finds a way to do so!

The second leg of the proportionality review looks at whether the measure under review, the OMT programme does not go manifestly beyond what is necessary to achieve the objectives it purposes. This level of review is particularly difficult in the event that it is not even clear at the time of judicial review if and under which exact conditions that measure would be ever implemented. The in-depth discussion of the CJEU of this question shows just how far it is willing to go to humour the BVerfG in order to fully answer the question posed even in the absence of legally binding detailed information about the possible future act. After all, the object of review is not a legal act but an announcement at a press conference of the fact that the Governing Board of the ECB has decided that in future it may engage in certain activities. One might argue further in

\footnotetext{
42 Case C-62/14 Gauweiler and Others v Deutscher Bundestag (OMT) of 16 June 2015, ECLI:EU:C:2015:400, paras 72-80.

${ }^{43}$ Case C-62/14 Gawweiler and Others v Deutscher Bundestag (OMT) of 16 June 2015, ECLI:EU:C:2015:400, para 71.
} 
favour of proportionality review of this matter by the CJEU that the announcement of the ECB - a factual as opposed to a legally binding act - may have effects on the markets through regulation by information and may affect, if implemented, the budgetary interests of the shareholders of the ECB which are the National Central Banks backed by the Member States. These considerations will have together led the CJEU to enter into a more detailed discussion of these matters in this context.

Needless to say, as the CJEU does, that the conditions discussed in the second aspect of proportionality here require that the bond purchases by the ECB cease as soon as the ECB's objectives have been achieved. ${ }^{44}$ However, the determination of this very moment is in the ECB's discretion. This criteria is therefore not a very powerful criteria for limitation and judicial review. The Court also points out that at the time of judgement two years after the announcement of the programme - it has not been implemented. The announcement as such having been effective to calm the markets therefore seems to have been effective and necessary to achieve the objectives of conducting monetary policy for the single currency, the Euro. Even if it were implemented, the Court continues its analysis of hypotheticals, the announcement contains sufficient limitations as to which bonds would be purchased. The selection of bonds only from EFSM and ESM 'programme countries' would ensure that the bond purchases would not disturb the general economic policy objectives of the Union. This selectivity is regarded as part of the limitations rendering the measure proportionate and not one of the matters which show that the measure is in fact an economic policy measure disguised as monetary bond buying programme. In view of the nature of the German concerns, importantly the CJEU in para 88 of its judgement states that these limitations of the potential bond buying programme would be sufficient. No total cap of money spent on bond buying programmes is necessary.

Interestingly, the Court does not apply the usual formula for the second leg of the proportionality test, which it uses generally for balancing decisions or limitations of rights: For example, in Afton Chemical the Court citing a long line of precedent restates its formula that 'when there is a choice between several appropriate measures recourse must be had to the least onerous'. The notion of 'least onerous' therefore requires a clear definition of the rights in question and of balancing. It would appear that the CJEU avoids this formulation in order to avoid accepting that at the end of the day the budgetary rights of the Member States are in question. Therefore the CJEU retreats to the more general formulation used occasionally in pure 'limitation of competence' or with other words 'conferral' questions and cites instead Association Kokopelli, a case with a particularly limited reading of the criteria for review of proportionality, as precedent of

${ }^{44}$ Case C-62/14 Gawweiler and Others v Deutscher Bundestag (OMT) of 16 June 2015, ECLI:EU:C:2015:400, para 82. 
the formulation of the criteria of proportionality in this case. ${ }^{45}$ Interstingly, the CJEU decides actively to reduce its level of review as compared to the AG who in para 177 of his opinion refers to more onerous second-leg proportionality test by looking for whether 'the means used may none the less be excessive if compared with the other options that would have been available to the ECB.' ${ }^{\prime} 6$

As a result, the Court finds that since the conditions for the OMT programme include strict limitations to objectives pursued and is limited to certain types pf bonds issued by Member States selected on the basis of pre-defined criteria the measure is not manifestly beyond what is necessary to achieve the ECB's monetary policy objectives. Limiting the proportionality review here, might become the most problematic element of the case, and I would predict, would constitute its weakest point. It is a failed opportunity to conduct proportionality review to a degree which would even be convincing to the openly critical BVerfG.

The third leg of the proportionality test, finally, consists of analysing whether the various interests in the case have been overall reasonably weighed up against each other - the so called proportionality strictu sensu. On the basis of the above discussions both the CJEU and the AG have no difficulties finding that this level of review is complied with. The general question to be asked, which underlies the German concerns in the originating case is what level of cost the monetary union might be worth to them. That is of course a question completely unsuitable for litigation and for a court to decide. Accordingly, the discussion is short on this matter.

\section{F Conclusion}

\section{TO BE DEVELOPED !}

So, have after all the exceptional emergency acts of the ECB - in this case the OMT decision - created through the subsequent judicial review fanything of value for concepts of European public law? What can be learnt from the OMT dispute?

I would suggest some first conclusions:

\footnotetext{
${ }^{45}$ See C-59/11 Association Kokopelli EU:C:2012:447, para 38. Kokopelli concerned a dispute between two seed dealing companies and the question whether seeds varieties not officially registered could be marketed. Kokopelli must be considered particularly narrow since the case actually affected rights of individuals which needed to be balanced.

${ }^{46}$ Citing C-331/88 Fédesa and Others EU:C:1990:391 para 13 and C-180/00 Netherlands v Commission EU:C:2005:451, para 103.
} 
The legal framework of EU economic policy of the EU is in the process of continuous transformation. The economic and financial crisis of the years after 2008 have been catalytic for accelerating integration. But some of these measures have gone deeper than simply strengthening the previous policy framework and have changed the details of the EMU roadmap both from an institutional and constitutional perspective. Monetary policy excised in the ESCB's specific structure of de-centralised Union administration is a case study of a highly integrated agency regime which no other EU policy area has reached. At the same time, EU monetary policy has become an exemplary field to study the independence of agencies, the powerful role which specific expertise is given in defining a highly relevant and specifically framed objective: that of guaranteeing price stability. This precisely defined policy goal shall be exercised where possible in the context of maintaining price stability to contribute to the 'general economic policies in the Union'. It is thus a technical objective which should be exercised also in the context of politically defined goals. Therefore, the administration of the Union's monetary policy is highly political administration.

However despite the many specific features, this area also presents itself as an area of study with a wealth of examples for many of the general characteristics and the problems of the fast evolving Union administrative law. ${ }^{47}$ One of the reasons for this is that normally, monetary and economic policies are quite well hidden away in the bowls of the state. Lawyers rarely venture into this field of high technical expertise and highly independent agencies. If at all, public law instruments of control of central banks are often centred on anticipatory modes of control through nomination of key personnel such as the central bank's president. Expost tools of review and accountability often are in the form of auditing reports and parliament hearings in which central bankers need to justify their decisions.

In the EU, this generally well hidden area has been brought to the broad light of day by the Treaty of Maastricht and Lisbon's distribution of powers concerning EMU along the various multiple levels of governance. Monetary policy was fully centralised in the ECB, economic policy largely remained in the hands of the Member States. This distinction proved to be an impossible approach and so since 2008 in a series of international agreements and EU legislation, economic policy has been brought into the realm of the executive branches of Member States coordinating on an intergovernmental level and the EU Commission. In view of this, the ECB is supposed to exercise its objective of maintaining price stability whilst nonetheless supporting the economic policy objectives formulated in within the EMU. In doing so, however, it has to navigate the particular, and one might add as

\footnotetext{
${ }^{47}$ Herwig C.H. Hofmann, Gerard C. Rowe, Alexander H. Türk, Administrative Law and Policy of the European Union, Oxford University Press (Oxford 2011), 18.
} 
the 2008 crises has shown, quite possibly over-optimistic or even naïve, hope that the 'invisible hand' of market pressures will lead to a fully-fledged coordination of growth oriented economic policies of the Euro Member States. Instead, the ECB finds itself in a situation where it has to define monetary policy in view of markets, which can over- or under-price certain risks. Speculation is a strong force in creating prices. In that situation, the ECB devised its OMT programme in order to counteract against speculation detrimental to the existence of a single monetary policy.

In view of this, at the end of the day, the dispute before the BVerfG arose from the fear that the German Parliament having the ultimate budgetary rights in Germany, would be exposed to undefined financial liabilities resulting from ECB action on bond markets trying to stem speculation and maintain the unity of the Eurozone. The fear was that by buying bonds, the ECB would actually risk bankruptcy itself and thus in need of being bailed out by its shareholders - the national central banks. Also, the fear was that the ECB would indirectly engage in monetary financing of state budgets in that it would buy government bonds by circumventing the prohibition of monetary financing of budgets in Article 123(2) TFEU.

The dispute has therefore brought to light a serious design flaw in the EU's EMU. It is difficult to maintain in extreme situations one monetary union in absence of a common fiscal and economic policy which would be capable of raising itself enough money to back up the ECB's monetary policy actions. This structure limits both the monetary as well as the economic policy options of the EU and the Member States. Instead of classic neo-functionalist spill-over, the reality is that the ECB is fighting against a speculation based roll-back of integration in a way not un-similar to the exchange rate troubles of the early 1990ies which affected both Sweden and the UK.

With respect to the possibilities of judicial review of the actions of central banks, Gauweiler marks a big step towards developing accountability in legal terms whilst respecting technical expertise and the discretion which has been conferred on the $\mathrm{ECB}$ in order to back that up. The key instrument in EU law to navigate the treacherous waters of ensuring legality and accountability of acts on one hand and protecting discretionary power has consisted in fine-tuning the review under proportionality. The CJEU takes the right steps to submit ECB action to the proportionality test. But much needs to be done to better develop the criteria of proportionality whose exact application remains in a state of flux. Just by comparing the precedents the CJEU and the AG rely on in definition of their proportionality criteria makes clear, how much work needs to be done in this context. 
Another interesting point which was developed in this case, in response to the pressure exercised by the BVerfG, is the possibility of review of what generally might be regarded as a 'factual act' as opposed to a legally binding act. The announcement of a programme which was yet to be defined in legally binding acts was submitted to review to answer the question of the BVerfG. The definition of the degree of sub-elements of the programme was unclear. Therefore, the Court essentially reconfirmed a structure of review for all such not-fully defined types of act, be they factual acts, be they programmes of unclear legal status to be later specified: The single approach to their review is to control the existence of a legal basis, the compliance of the measure with all specifications of the legal basis and, finally, a test as to the compliance of the measure with general principles of EU law, which in all practical terms often means essentially the compliance with the proportionality test. 